\title{
Legal Policy Granting Status of Fresh Start to the Individual Bankrupt Debtor in Developing the Bankruptcy Law in Indonesia
}

\author{
Kurnia Toha \\ Sonyendah Retnaningsih \\ Universitas Indonesia, \\ Jakarta, Indonesia
}

Doi: 10.36941/ajis-2020-0033

\begin{abstract}
The objectives of this research are to identify and assess the granting of discharge as of debt in the bankruptcy law in Indonesia and legal policy regarding granting status of fresh start to individual debtors, which are in a good faith and is not able, after termination of bankruptcy, in order to develop bankruptcy law in Indonesia. The analysis is directed to explain the legal policy on granting status of fresh start to the individual bankrupt debtor in order to develop the Bankruptcy Law in Indonesia. Bankruptcy was originally conceived as a punishment for an act that is considered a criminal conduct because of the debtors' bad faith to avoid debt. Modern bankruptcy law is aimed as an exit from financial distress. The bankruptcy law system in Indonesia adheres to a principle of "debt collective" which comes in the form of a general seizure over the debtor's bankruptcy assets as collateral for debts repayment. This study offers an novelty in that bankruptcy law in Indonesia does not adhere to the principle of "debt forgiveness", in which bankruptcy is a legal institution used as a way to ease the burden of debtors due to financial difficulties through the form of elimination of individual debtor's remaining debt. After the bankruptcy ends, creditors obtain his execution rights over the property rights of the debtor, particularly on the receivable that have not been fully paid which the debtor is obligated to pay up in full.
\end{abstract}

Keywords : bankruptcy, debtor bankrupt individual, fresh start

\section{Introduction}

Bankruptcy was originally considered as a verdict for a criminal act, because the debtor is considered evasive or unwilling to pay his debts to the creditors. Bankruptcy is a punishment for debtors who do not pay his debts, and for the bad faith of the debtors who deceive and hinder creditors to collect their debts by hiding assets. Bankruptcy is also considered as a debtors' fault, because the causes of failure is in their lack of efforts, so that the debtor cannot pay his debts to creditors. The debtor, who is not able to pay the debts, is to be put in prison and their assets are to be taken and sold as the fulfilment of debts to the creditors (Nurdin, 2011).

In further development, bankruptcy is no longer regarded as a punishment or a humiliation for the debtor, but rather as a debtors' lack of luck, causing them to have a financial difficulty. Modern bankruptcy law was created as a way out for the debtors who are experiencing financial distress to not continuously be billed to pay the creditors, and at the same time to provide access for the creditors to be able to possess the assets of the debtor as a repayment of debts, although it is often 
insufficient. Thus, bankruptcy no longer functions as a punishment, but as a way out to solve the problem of debts to creditors (Juwana, 2004; Mulyawan, 2018).

Bankruptcy law system in Indonesia adheres to the principle of a debt collection which is stated in the Article 1 paragraph 1 of the Bankruptcy Law and Suspension of Debt Payment. The principle of a debt collection focuses on the debtor's debt to be paid with property owned by the debtor as soon as possible to avoid the bad faith of the debtor by hiding and disclaiming their property as collateral repayment to the creditor (Shubhan, 2019). In the past, this principle is manifested in form of slavery, cutting the body of the debtor, and imprisonment, but in the era of modern bankruptcy law, the principle of a debt collection is moved to the form of liquidation of assets (Yuhassarie, 2005).

Bankruptcy law in Indonesia does not recognize the principle of debt forgiveness, which means that bankruptcy is a legal order that is used as one way to ease the burden of debtors due to financial difficulties resulting in inability to pay its debts which have became matured, by providing debt relief through the elimination of the remaining debt, so that the debtor can resume the business without the burden of the previous debt. The principle of debt forgiveness is implemented by providing debt relief for the debtors who are unable to pay off debts (discharge of indebtedness); and granting the status of fresh start for the debtors to provide new life opportunity and to start a new venture without being penalized by the debts of the past (Subhan, 2009).

The Article 204 of the Bankruptcy Law and Suspension of Debt Payment states that after the distribution list becomes final and binding, the creditors repossess the rights of enforcement against the debtor's assets to cover their unpaid claims. Therefore, if the liquidation has already been done by the curator, there are still debtors' outstanding debts. Even though the bankruptcy estate has been sold and is divisible, the debtor is obliged to repay to creditors who are still entitled to collect the rest of the receivable. This condition will certainly make it difficult for bankrupt debtors particularly an individual bankrupt debtor to raise up and try again, because the individual bankrupt debtor will continue to be overshadowed by his previous debts to creditors, as long as the debt is not yet repaid. The remaining of the debt will continue to haunt the individual bankrupt debtor, even allowing debtors to be bankrupt for the second time (Wijaya, 2005).

It is certainly different from the bankrupt debtor in the form of a legal entity such as a limited liability company. Article 142, paragraph 1, letter d, of Law No. 40 of 2007 concerning limited liability company states that if the bankruptcy estate is insufficient to pay the debts, by law that insolvent company will be dissolved, so it will not bear the burden to pay off the remaining debt after the bankruptcy ends (Asyhadie \& Sutrisno, 2012). The condition is certainly considered unfair by individual debtors, because individual debtors will continuously be haunted by the remaining debt until it is being paid off. In contrast, the debtor in form of company can dissolve itself, when it is being declared bankrupt and no longer bear the burden of the remaining debt. This is not considered in line with the principles on which the formation of the Bankruptcy Law and Suspension of Debt Payment as mentioned in the explanation. It mentions that the Bankruptcy Law and Suspension of Debt Payment is based on the principles of balance, fairness, business continuity, and integration. The subject matter of the research is aimed at analyzing the procedure to eliminate the debt of the individual bankrupt debtors in the Bankruptcy Law in Indonesia. Moreover, the analysis is directed to explain the legal policy on granting status of fresh start to the individual bankrupt debtor in order to develop the Bankruptcy Law in Indonesia.

\section{Elimination of Debts against the Individual Bankrupt Debtor in Bankruptcy Law in Indonesia}

Bankruptcy Law System in Indonesia adheres to the principle of debt collection through general seizure on the property of the debtor as payment guarantee for debts by a bankruptcy institution. According to the principle of debt collection, bankruptcy is a liquidation process as a measurement over the bankruptcy estate in order to enable fair distribution of debt payment among the creditors. Bankruptcy Law is needed as collective proceedings. Without bankruptcy law, the creditors will be 
competing individually to claim control over the debtor's property which interests each creditor. Therefore, the bankruptcy law overcomes the so-called collective action problem, that arises from the individual interests of each creditor. Through bankruptcy law, a mechanism is provided by which creditors can come together to determine whether a debtor can carry out their business or not. Bankruptcy serves as a means of coercion for the realization of the rights of creditors through liquidation of the debtor's assets. Bankruptcy is seen as a way to recover the debts of the debtor through liquidation of its assets, so bankruptcy focuses more on a debt settlement through liquidation of the debtor's assets (Subhan, 2009).

The Bankruptcy Law and Suspension of Debt Payment do not recognize debt forgiveness. Article 204 on The Bankruptcy Law and Suspension of Debt Payment states that after the distribution list becomes final and binding, the creditors repossess the rights of enforcement against the debtor's assets to cover their unpaid claims. Thus, after the bankruptcy ended, and there are debts that remained unpaid, the creditor is entitled to collect the remaining debts from the debtor. The remaining debts must be paid by the debtor to the creditors who are entitled to collect the remaining debt even if the debtor assets are all sold out (Nurdin, 2011).

This means that the debtor will not obtain debt relief. The remaining unpaid debt will continue to follow the debtor until the debt is paid in full. Thus, the Bankruptcy Law and Suspension of Debt Payment does not recognize debt relief, because creditors still have the right to collect on receivables that have not been paid in full by the debtor even if bankruptcy has ended. The debt cannot be erased by a debt relief mechanism and bankruptcy system in Indonesia does not recognize fresh start after the bankruptcy, which could gives the status of the debtor bankrupt individuals clear at all of the old debts.

It is different from the bankruptcy laws in United States, The Netherlands, and Singapore. In the United States, there are two policies attached to the bankruptcy code that gives debtors a fresh start through debt relief and fair distribution of wealth among debtors by creditors through liquidation (Jackson, 1986). Debt relief is granted by the court. It means that the debtor no longer has a legal obligation to pay off debts that have been released, although it does not eliminate the moral obligation of the debtor to pay the debt (Summers, 1989). Debt relief releases the debtor from personal liability against some types of debt that is specially regulated. It means the debtor does not have a legal obligation for the debts waived (Blum, 1998).

In the Netherlands, the Debt Restructuring of Private Individuals Act has been merged into the third book of Faillssementswet and came into force on December 1, 1998. This arrangement ensures the person who finds oneself in a financially difficult situation, is not haunted by the debt for years. The core of the arrangement is to provide the possibility of a the person, in terms of the debt, to make a fresh start without being chased by creditors (DeFalaise, 2005). In Singapore, the provisions of the bankruptcy of the individuals are arranged in the Bankruptcy Act. Under the provisions of article 123 to 127 , a debt relief of the individual bankrupt debtors cannot be obtained automatically. The individual bankrupt debtors will gain exemption after they receive an exemption certificates, issued by the officials with the following considerations:

1. it has reached the period of three years since the date when the debtor is declared bankrupt;

2. the amount of debt is no more than $\$ S 500,000$, when the debtor is declared bankrupt (Kamarul, 2006).

\section{Legal Policy on Granting Status of Fresh Start to Individual Bankrupt Debtors in Order to Develop the Bankruptcy Law in Indonesia}

The Bankruptcy Law and Suspension of Debt Payment is the starting point of bankruptcy law reform in Indonesia by making changes to the bankruptcy law produced by the colonial government, that is considered incompatible with the spirit of the Indonesian nation. It is reformed into the bankruptcy law that is more comprehensive and suits the people's need and the change of an era. The Bankruptcy Law and Suspension of Debt Payment should provide legal protection not only to creditor to obtain 
repayment of its receivables from the assets of the debtors, but also to the debtor, that is not able and with good faith to repay debts, to be freed from the remaining debt after the bankruptcy ends. It will provide the opportunity for the debtor to get back to meet their obligations and obtain a minimum of material well-being such as food, drinking water, and housing in order to increase individuals who collapse after the bankruptcy.

Pancasila, the principles and philosophy of the nation, is the crystallization of the noble values of the nation of Indonesia. The third principle of Pancasila seeks to prioritize social justice for all Indonesian people and the fourth principle aims to guarantee justice for all human beings and civilized national legal system. The reformation of The Bankruptcy Law and Suspension of Debt Payment is due to provide protection and fair treatment as well as balance to stakeholders, namely creditors, debtors, and society. In the business world, a fast, fair and efficient settlement of the debts will bring a positive impact on the economic stability and growth of the national economy (Sjahdeini, 2009).

Changes in bankruptcy law in Indonesia from the colonial products to national products as a means of legal settlements of debts in a fast, fair, open and effective politics must not be separated from the underlying legal political formation. Legal policy, as a part of state policy with respect to laws or regulations in force in a country, can be used as the legal basics of all policies of government agencies. Legal policy covers the manufacturing process and the implementation of the law to show the nature and direction of where the law will be enforced (Muladi, 2013). Legal policy on the bankruptcy law in Indonesia will determine the direction, the form, and content of legislation that will be established in the coming future (Wahjono, 1986). It is confirmed that politics plays a very important role in the development process of law. The implementation of law will govern the political life of society rooted in law (Suherman et al., 1988).

The general explanation of the The Bankruptcy and Suspension of Debt Payment Law states that it is created to prevent abuse of the institution of bankruptcy by creditors and debtors that have bad faith. In consequence, the law must protect the debtors that act in good faith. In the United States, the Netherlands, and Singapore, there are requirements of good faith to provide debt relief (Subhan, 2009). Debt elimination is the legal embodiment of the idea on fresh start. Fresh start in bankruptcy is a relief to debtors who are honest and do not do things to avoid debt (Summers, 1989). Fresh start philosophy is designed to forgive and give debtors a chance of reintegration into society. Substantially, fresh start frees the debtors from their debts after they file for bankruptcy petition and hand the bankruptcy estate for distribution to creditors, but not enough to pay off debts (Ziegel, 2004).

In Indonesia, the provision of debt relief has not regulated in The Bankruptcy Law and Suspension of Debt Payment. But in other economic law, it is already set up, for example in the banking sector, that is set on the provision to remove the book and remove payments. A Policy regarding debt forgiveness also been awarded on the BLBI cases through "Release and Discharge". Regulation on the elimination of receivables is also stipulated in the Government Regulation No 14 of 2005, which revised by Government Regulation No 33 of 2006 regarding the procedure for the elimination of receivables countries/regions. Credit losses are also regulated by common agreement between the governor of Yogyakarta, Bank of Indonesia, and Commission VI of the House of Representatives on 11 February 2011, which essentially clearing credits for small and medium enterprises affected by the 2006 earthquake. Therefore, given that in the business world, a risk of business bankruptcy can happen, especially in cases of force majeure which causes the debtors to be bankrupt, it is necessary to set norms concerning the elimination of debt in The Bankruptcy Law and Suspension of Debt Payment.

In relation to the granting of fresh start status in bankruptcy law in Indonesia, it is needed to establish an upcoming bankruptcy law, so bankruptcy law political direction forward is set to provide legal protection to the debtor bankrupt individuals, who are insolvent and in good faith. Through the concept of fresh start in The Bankruptcy Law and Suspension of Debt Payment, it is expected that in the future the law could provide not only the creditor, but also debtor acting in good faith and 
insolvent, so that debtors do not continuously pursue remaining unpaid debt after bankruptcy, but it also gives legal certainty and a sense of justice to the debtors after the bankruptcy liquidation process is completed. It is expected to arrange debt relief as a form of manifestation fresh start to the individual bankrupt debtors in the upcoming bankruptcy law, so that it will provide a balance protection, not only to creditors in getting repayment of loans, but also to individual debtors who are insolvent and in good faith by providing legal certainty and justice for the rest of the debtor's debt to creditors after the bankruptcy ends.

\section{Conclusion}

The bankruptcy law and suspension of debt payment applies the principle that debts cannot be erased with debt relief. In the Indonesian Bankruptcy Law, the individual bankrupt debtor's debt will continue to follow until the debt is paid off. It even allows bankrupt debtors to be declared bankrupt more than once. Thus, even if the bankruptcy has ended and there are still remaining unpaid debt, the creditor is entitled to collect the remainder of the debt from the debtor. This means that the debtor will not get debt relief. The political direction of granting the status of fresh start to the individual bankrupt debtors in order to develop bankruptcy law Indonesia is to provide legal protection to the individual debtors who are insolvent and in good faith, with the opportunity to try to come back without being burdened by debts in the past through a debt relief after the bankrupt ends. Through the granting of status of fresh start to the individual bankrupt debtor, it will give legal certainty on the remainings of past debt after the termination of bankruptcy and guarantee justice to rise up and try again in order to resume life and free from the fear of being chased by debts from the past.

\section{References}

Asyhaddie Z., \& Sutrisno, B. (2012). Hukum Perusahaan dan Kepailitan. Jakarta : Sinar Grafika.

Blum, B. A. (1998). Bankruptcy and debtor/Creditor: Examples E Explanations. New York : Aspen Law \& Business.

DeFalaise, M. A. (2005). Means Testing and Preventing Abuse by Consumer Debtors, Bankruptcy Abuse Prevention and Consumer Protection Act of 2005 I. US Att'ys Bull., $54(2)$.

Jackson, T. H. (2001). The logic and limits of bankruptcy law. Beard Books.

Juwana, H. (2004). Pailitnya Prudential, Harga Mahal Panasea IMF. Kompas.

Kamarul, B. (2006). Insolvency Law in Malaysia, In Tomasic R. (Ed.), Insolvency Law in East Asia (pp. 321-354). Hampshire, England: Ashgate Publishing Limited.

Mulyawan, H. (2018). Functions of Financial Services Authority in Supervision of Auto Insurance Companies. Asian Journal of Law and Jurisprudence 1(1).

Nurdin, A. (2012). Kepailitan BUMN Persero Berdasarkan Asas Kepastian Hukum. Bandung : Alumni.

Sjahdeini, S. R. (2009). Hukum Kepailitan Memahami Undang-Undang No. 37 Tahun 2004 tentang Kepailitan. Jakarta : Pustaka Utama Grafiti.

Subhan, M. H. (2009). Hukum Kepailitan: Prinsip, Norma, dan Praktik di Pengadilan. Jakarta: Kencana Prenada Media Group.

Shubhan, M.H. (2019). Misuse of Bankruptcy Petitions by Creditors: The Case of Indonesia. International Journal of Innovation, Creativity and Change 10(6), 195-207

Suherman E. (1988). Faillissement (Kefailitan). Bandung: Binacipta.

Summers, M. S. (1989). Bankruptcy Explained A Guide For Business. Texas: John Wiley \& Sons.

Wahjono, P. (1986). Indonesia Negara Berdasarkan Atas Hukum. Jakarta: Ghalia.

Wijaya, G. (2005). Seri Hukum Bisnis : Daluwarsa. Jakarta : RajaGrafindo Persada.

Yuhassarie, E. (2005). Prosiding Rangkaian Lokakarya Terbatas Masalah-Masalah Kepailitan dan Hukum Bisnis lainnya. Jakarta : Pusat Pengkajian Hukum.

Ziegel, J. S. (2003). Comparative consumer insolvency regimes: A Canadian perspective. Hart Publishing. 